\title{
Students' Understanding on Spoken Discourse in The Context of English Language Teaching (ELT) at University
}

\author{
Dias Andris Susanto', Masitoh Oktavia², Lina Tri Astuty Beru Sembiring ${ }^{3}$ \\ Universitas PGRI Semarang'1, Ma'had AL Islam Surakarta², Universitas Dehasen Bengkulu \\ Email: diasandris@upgris.ac.id ${ }^{1}$
}

Submitted: 18/01/2021

Revised: $29 / 01 / 2020$

Accepted: 10/02/2021

\section{E-ISSN : $2579-4574$}

P-ISSN : 2549-7359

\begin{abstract}
This is a case study on students' understanding towards a subject of discourse analysis at English language education study program at University in Indonesia. The goal of this study is to describe the definitions, the examples, and the applications of spoken discourse analysis on their context of English language teaching (ELT). The writers used qualitative research approach to analyze these data through implementing Atlas.ti8 which is known as the tool of analyzing the field qualitative data. The sample was the students of $7^{\text {th }}$ grade semester consisting 30 people. In collecting the data, we used online direct interview in the classroom and by time they replied the questions on the time using the google form by Microsoft. In analyzing the data, we used atlas.ti. 8 online to draw the result of the research as followings; that students' understanding about the definitions of spoken discourse analysis have some various key terms like; -a research method of spoken language, -knowledge of language, how language used, study of language, and study of the texts. Then, its examples are; they can picturize as; speaking on the phone, conversation, interview, putting markers, turn taking, group of discussion, using advertisement, people interaction, joke, speech, also transferring information. Moreover, its applications are such as; communicating with teachers/parents, interacting with students/people, go to the market, baby crying, ceremony, and communicating with friends. The conclusion is that spoken discourse analysis has been understood by students even though it is not easy to define, giving example and declaring the application in the real context English language teaching.
\end{abstract}

Keywords: students' understanding, spoken discourse analysis, ELT

\section{https://ojs.unm.ac.id/eralingua}

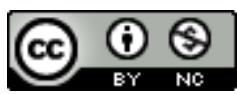

This work is licensed under a Creative Commons Attribution-NonCommercial 4.0 International License 


\section{INTRODUCTION}

People using language as the means of communication to get the interaction and social needs to be melted in the society. The interaction will be lost if one of the communication factors is disappear like, meaning. We need a meaning to connect our cognitive paradigm to the receivers. We need discourse to bridge this meaning to the people we interact with. Here we focus on the meaning as called discourse analysis as the main topic of this research.

Discourse analysis materials is one of the important subjects learnt in English education department which is homed at its curriculum. In Indonesia, especially at the university that conducts the English education department usually bridging students with this discourse analysis (DA). Dahal (2010) stated that discourse analysis (DA) has emerged as a fast-growing discipline because of growing interest of linguists in studying language in natural setting, as opposed to making analyses of artificially created sentences. This study reveals a simpler structure of classroom discourse than the one mentioned by Sinclair and Coulthard (1992).

Discourse analysis is the study of how stretches of a language used in communication assume meaning, purpose and unity for their users: the quality of coherence (Johnson \& Johnson, 1998). In fact, many students feel hard joining the understanding of the concepts about discourse analysis. Even though, I do believe that discourse analysis is the examination of language use by the members of a speech community. It involves looking at both language form and language functions and includes the study of both spoken interaction and written text (Demo, 2001).

Spoken discourse is highly informal and complex in its structure. McCarthy (1991) says, "Spoken language is a vast subject, and little is known in hard statistical terms of the distribution of different types of the speech in people's everyday lives." Spoken discourse includes mostly phrases and incomplete sentences, and includes many pauses and hesitations. Moreover, spoken discourse refers to reciprocal types of discourse in which the sender can check reception and adjust to it.

Students' understanding in spoken and writing discourse when they were study in their class. Teacher play an important role too to develop the students interest and toward a subject or the language. Based on the study from British Council (2015), English learners in Ecuador show more confidence at the time of reading and writing but they do not have much confidence in speaking. English learners consider speaking harder than writing and reading and the only contact they have with the language is in classes, besides that, they do not count on teachers who use appropriate strategies to encourage them to produce the language in language teaching.

The importance of materials in language teaching and learning has been extensively acknowledged (McGrath, 2013). Teaching materials are a key instrument in most language courses. Language teaching throughout the world today could not be more successful without the extensive use of commercial materials (Richards, 2001). Nunan (2001) argues that classroom texts and dialogues are inadequate for learners for coping with the language they hear and read in the real world outside 
the classroom. To grasp aural and written text in the real world, learners need opportunities for engaging in these real-world texts in class. Nunan then endorses two types of authenticity: input and activity broadly based on the tasks in the language classrooms. Hutchinson and Waters (1987) evaluate authenticity in terms of ESP. According to them, authenticity is not idiosyncratic of a text in itself rather a feature of a text in a particular context. The implication of a text is not inherent to the text, but arises from the role of the text has to play in the teaching and learning process.

This research needs to be conducted urgently since a discourse analysis as one of subject lessons at the English education study program in which is difficult to teach in the domain of English language teaching. Students feel difficult to absorb and understand discourse analysis in the context linguistics not the context of English language teaching. Here the writers digged up students' understanding regarding their opinion towards the subject of discourse analysis beyond the context of language teaching. Research problems; They are as followings; how do students understand the spoken discourse towards on its definitions, examples, and applications in their contexts of ELT?

\section{Review of Related Literature}

Dijk (1997) mentions that discourse is a form of language use which includes the functional aspects of a communicative event. 'Pragmatic connectives' (Van Dijk, 1979), 'discourse particles' (Schourup, 1985) and 'discourse connectives' (Warner, 1985; Blakemore, 1987) have been used to refer to DMs, which have been tackled from three different approaches. Studies on discourse analysis have been conducted by (Sofwan, 2011; 2014; 2015; 2017). Sofwan (2011) declares that speaker's vision and attitudes through deictic expressions show that the speaker used various types of deixis, including person, place, and time deixis. Person deixis was used to introduce Timorese people, whereas more time deixis referring to present time was used to focus his attention on the present situation and did not want to turn back to the past experience with full of political and social conflicts. The speaker's vision is reflected in the use of the first person plural 'we' more than the first person singular 'l' or 'me'. After that he (2015) also states that the analysis of students' engagement to writing feedback activities viewed from students' writing anxiety can be inferred that in the implementation of teacher feedback, it was found some problems related to students' engagement; students' short concentration span, teacher's appropriation, students' reluctance and students' dependency.

McCarthy and Carter (2014) said that a traditional way of dividing language use applied in language teaching is spoken versus written. Some examples of spoken language that can be found in everyday talk are: -Telephone calls (business and private),-Service encounters (shops, ticket officers, etc.),-Interviews (jobs, journalistic, in official settings),-Classroom (classes, seminars, lectures, tutorials),Rituals (church prayers, sermons, and weddings),-Monologues (speeches, stories, jokes),-Language in action (talk accompanying doing: fixing, cooking, assembling, demonstrating, etc.),-Casual conversations (strangers, friends, intimates),-Organizing and directing people (work, home, in the street) McCarthy, 1991. 
Studies on ELT (English Language Teaching) have been conducted by Bharati (2010, 2016) ; Permatasari \& Bharati, (2015). Bharati (2010) developed procedure text material containing fun activities to strengthen the students' characters. She showed that the teachers only used textbooks, read them and asked the students to practice without any kind of enjoyable and fun activities and the students often felt bored. From the need analysis through questionnaire, the highest score of the activity needed was fun activities.

The other Studies on English Language Teaching are explained by (Mujiyanto,2016; Rosari \& Mujiyanto, 2016; Munir, 2013). Mujiyanto (2016) declares that the comprehensibility of readable English texts and their back-translations presents the results of a study initiated by the potential employment of readability measures to assess the equivalence of reading ease and grade level indices between source texts and their translations as well as back-renderings.

Riggenbach (1999) says that in spoken language, for example, teachers can help their students focus on particular grammatical structures in natural speech and observe what is actually said, may or may not conform to the prescriptive rules. He further says that students can observe grammatical structures (e.g. Verb tenses, the passive voice, article usage) as they appear in authentic spoken discourse, and then make hypotheses about why particular grammatical choices were made instead of others, which can ultimately lead to an outlining of the -rulesll that determine these choices.

\section{RESEARCH METHOD}

The participants of this research were there 30 students of English education study program who attended in the lesson meeting of discourse analysis subject in the $7^{\text {th }}$ semester. These students have not got any information about the domain of discourse yet. Gay and Airasian (2000) expressed that instrument is a device that is utilized in gathering information. Interview is action that includes questioner and interviewee where the questioner will give a few inquiries to be replied by interviewee. Ary et.al (1985) expressed "In an interview, information is gathered through eye to eye or phone cooperation between the questioner and the respondent".

At that point, Creswell (2002) additionally order the interview into four sorts, those sorts are (1) one-on-one interview, (2) center gathering interview, (3) phone talk with, (4) electronic Email meet. The technique of collecting the data, the writers used online submitting information through google form by Microsoft directing to students while they have its teaching interaction. In view of the kinds of interview over, the writers utilized an electronic online interview. As indicated by him, the data assortment that have got was measure in which the writers posed inquiries and records answers from the submission of students' answers at a time. To gathering information of meeting, the analyst makes a few methods. Those are (1) setting up the idea of inquiries that need to be posed to subject and (2) the writers recorded the aftereffect of interview.

The locus of this research was conducted at Universitas PGRI Semarang, Indonesia. This research design was a qualitative descriptive using the research tool Atlas.Ti8. The purpose of Atlas.ti8 is to help writers uncover and systematically 
analyze complex phenomena hidden in unstructured data (text, multimedia, geospatial). The program provides tools that let the user locate, code, and annotate findings in primary data material, to weigh and evaluate their importance, and to visualize the often complex relations between them. Atlas.ti8 is used by researchers in a wide variety of fields including language works. Generally, the qualitative research approach concerns itself with the meanings and experiences of the "whole" person or local culture and context (Winter, 2000).

To analyze the data, the writers used some following steps: 1 ) collecting the data: the writers collected all the online students' answers on the online interview that they have sent through google form online sheet which were about students' understanding about the definition of spoken discourse analysis, the examples of usage of spoken discourse analysis, and the application of spoken discourse analysis in the context of language education. 2) documentation: there were 30 documentations of students' arguments of the definitions, examples of, and the application beyond the spoken discourse analysis. The writers documented them into tabulation on listed answers. 3) classification: afterwards, the writers then classified students' answers through based on the variable of definitions, variables of examples, and variables of the application onto the spoken discourse analysis. Lastly, 4) interpretation: the writers took the mostly appeared 7 students' answers to have inductive interpretation towards the conclusion of the students' understanding on the spoken discourse analysis.

\section{RESULT AND DISCUSSION}

The writers have already collected the data that gotten from the students using google form digging up the students' understanding about the definition, the examples, the application of the spoken discourse analysis against the domain of students' knowledge. Here is the result of research analyzed using the tools of atlas.ti8.

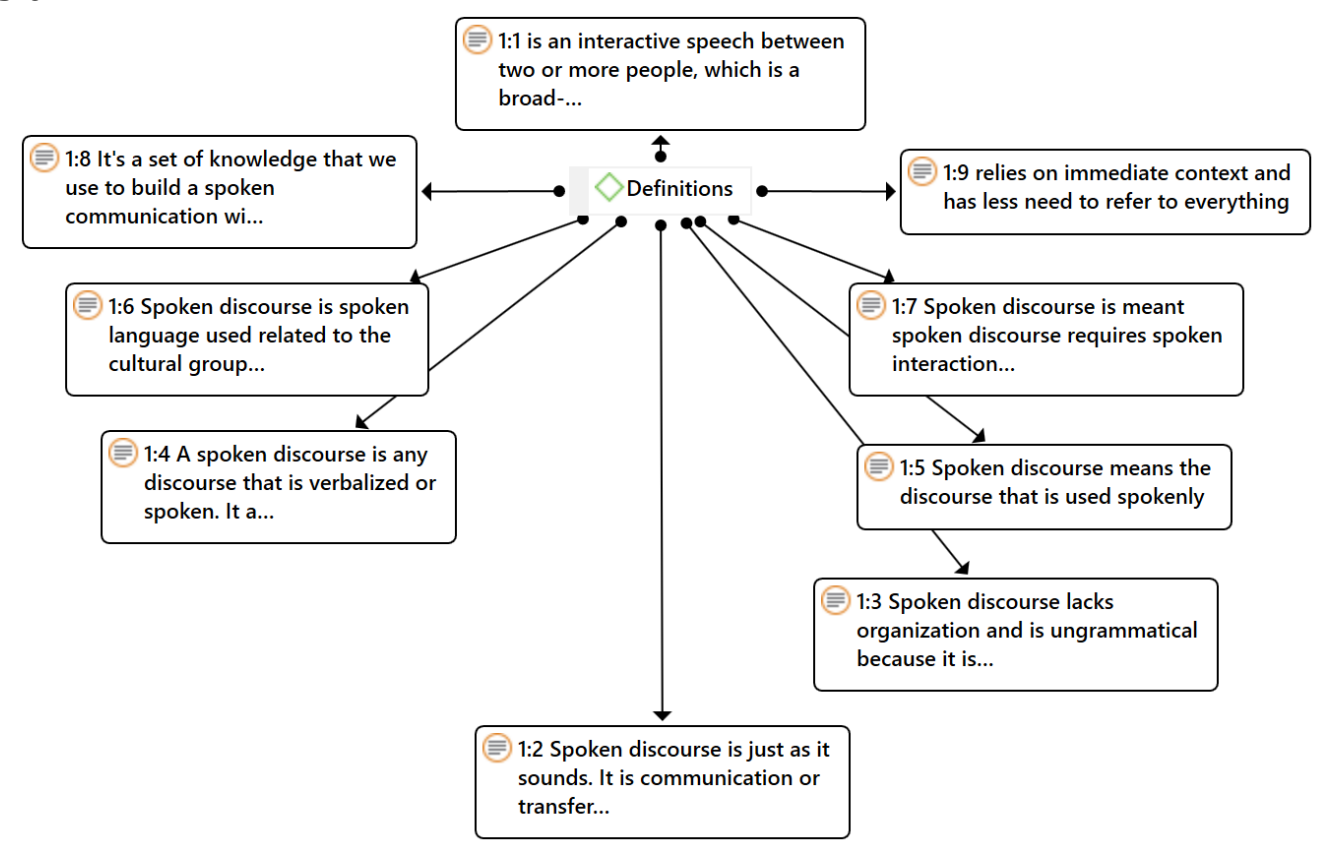

Figure 1. atlas.ti8 students' understanding on definition of spoken discourse 
Here is the figure 1 describes that students have various opinions on their own paradigm towards the question of what is the definition of discourse analysis. There are some answers which were already collected by online interview using google form like this following; $1^{\text {st }}$ Spoken discourse means the discourse that is used spoken, $2^{\text {nd }}$ spoken discourse is an interactive speech between two or more people, which is a broad-based language phenomenon in daily life, $3^{\text {rd }}$ Spoken discourse is just as it sounds. It is communication or transfer of information using words that are spoken, $4^{\text {th }}$ Spoken discourse lacks organization and is ungrammatical because it is spontaneous, whereas written discourse is organized and grammatical, $5^{\text {th }} \mathrm{A}$ spoken discourse is any discourse that is verbalized or spoken. It also generally referred to as speech, $6^{\text {th }}$ Spoken discourse is spoken language used related to the cultural groups and context, $7^{\text {th }}$ Spoken discourse is meant spoken discourse requires spoken interaction contexts of utterance which obtain in the production and reception of spoken and written discourse, $8^{\text {th }}$ It's a set of knowledge that we use to build a spoken communication with other people, $9^{\text {th }}$ spoken discourse relies on immediate context and has less need to refer to everything.

The interpretation of research result towards the students' understanding on the definition of spoken discourse analysis defines that it deals with something uses and produces sounds, interaction and communication, transferring knowledge and information verbalized with the ungrammatical matters instead of considering culture and context which the speaker's context. This discourse is shaped by the context of culture and situation while the speaker and hearer conducting the communication and producing something spoken with the certain topic they have.

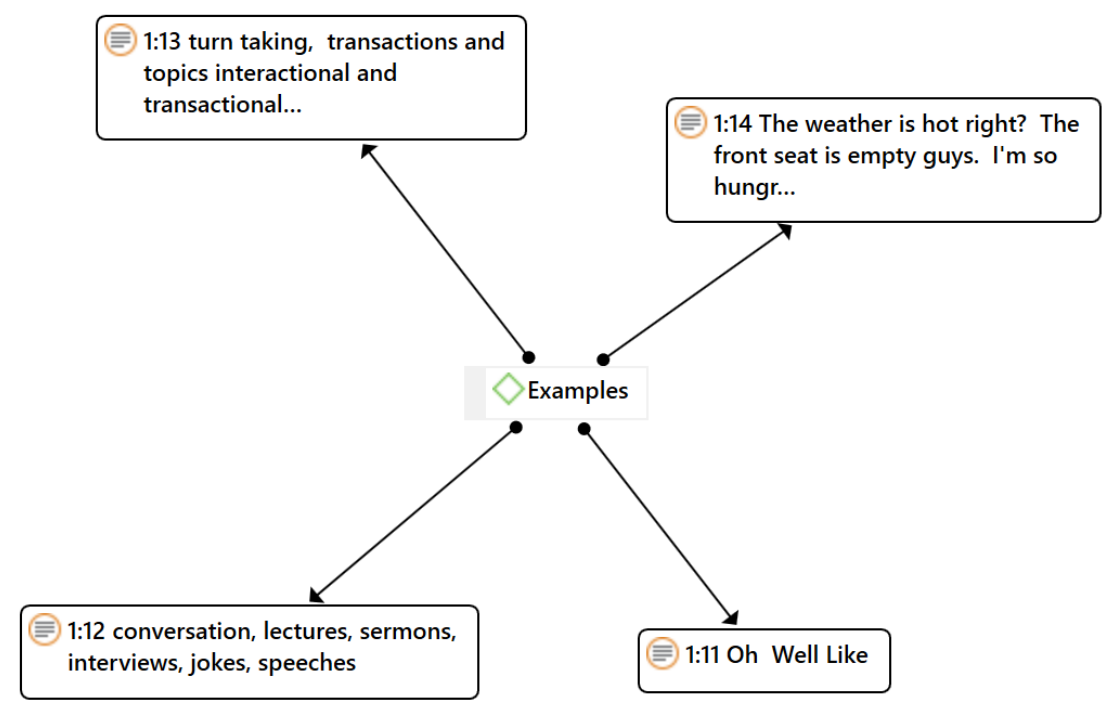

Figure 2. atlas.ti8 students' understanding on the example's usage of spoken discourse

1. The weather is hot right?

The front seat is empty guys.

I'm so hungry. 
2. Oh; Well; Like

3. Mmm; Hallo; Look

4. turn taking, transactions and topics interactional and transactional talk

5. conversation, lectures, sermons, interviews, jokes, speeches

6. this room is very cold means you have to turn off the AC/fan; this room is very hot meaning you have to turn on the AC/fan; I have no money means you have you give him/her money;

7. The context is in the class: Okay students, are you ready to our middle test. Using Body gestures or body language: *using the gestures to asking a drink. The word of "No smoking area", the people follow the instructions.

The interpretation of this research result elaborates that spoken discourse analysis occurs in some students' activities. Students five example in using spoken discourse while they do turn taking with their classmates, having lecturing while in the classroom, doing conversation with friends and lecturers, having jokes and speeches, joining the lecture at the classroom, conducting a interactional with colleges, and producing a transactional communication with people.

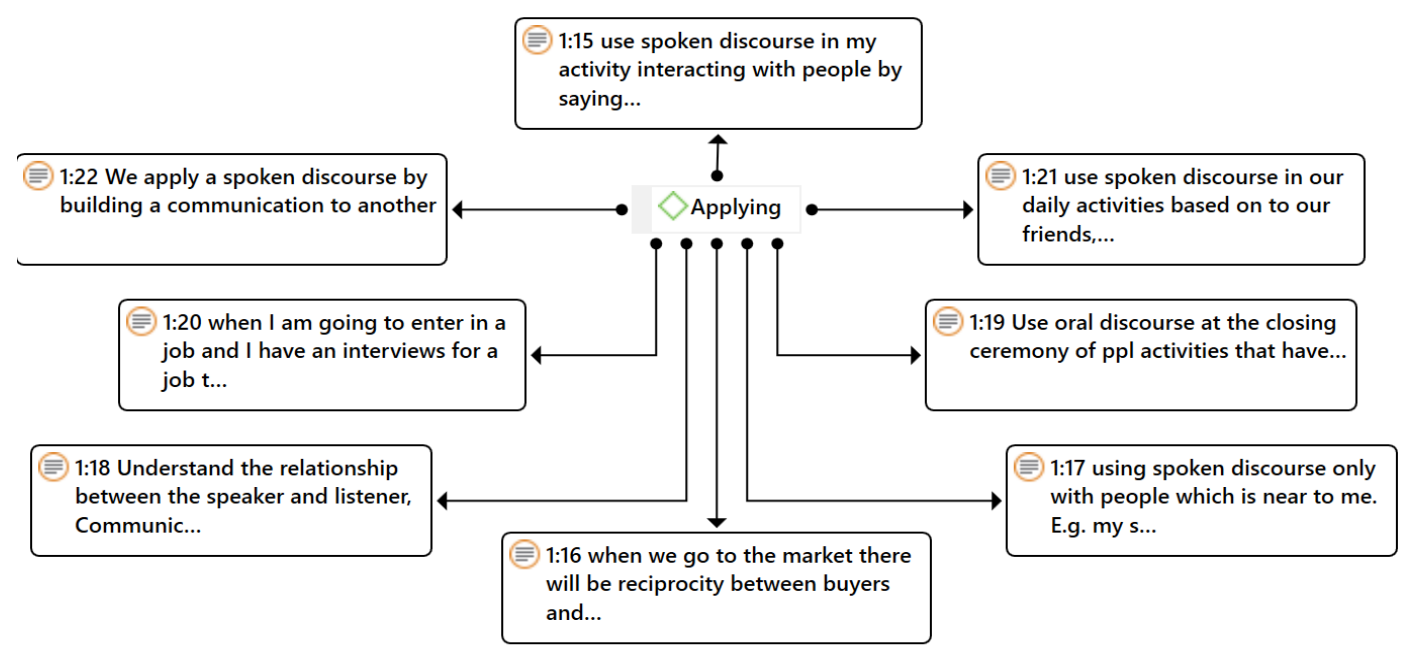

Figure 3. atlas.ti8 students' understanding on applying of spoken discourse

1. using spoken discourse only with people which is near to me. e.g., my students, my friends, and my family.

2. use spoken discourse in my activity interacting with people by saying (ex: ohh, well, like, mmm, er, ok, and hey).

3. when we go to the market there will be reciprocity between buyers and traders in terms of bargaining, as for when the presentation is in class.

4. Understand the relationship between the speaker and listener, communicate more effectively by understanding politeness and face.

5. Use oral discourse at the closing ceremony of ppl activities that have been going on for more than a month at school, giving the impression of a message and an apology in the activities so far. 
6. when I am going to enter in a job and I have an interview for a job that I want.

7. use spoken discourse in our daily activities based on to our friends, family, etc.

8. We apply a spoken discourse by building a communication to another.

The explanation on the interpretation results of this research conclude that the application of spoken discourse analysis might be applied by students while producing spoken markers like; English discourse markers, semantics markers, English fillers, agreeing and disagreeing, interviewing, giving speeches, sending oral messages, and impressing politeness within the dialogue, conversation and discussion.

Spoken discourse analysis is a subject for students of English education department which is the most subject that needs hard thinking and analyzing a lot. Including the spoken discourse, students are asked to give their own opinions about the definitions, examples and applications of spoken discourse in the real context of English language teaching (ELT). The most prominent definition of discourse analysis given by students is that they define discourse analysis is the study of language including words, clauses, phrases, sentences, and texts. Even though they have several definitions on discourse analysis but they mostly think that if we talk and learn discourse it will be about woman talks, men speaking, discussion of people, asking and giving information. Then the example that likely appeared is conversation on the phone. Finally, they also make an application of spoken discourse in social context as people interaction and communication.

Students have different perspectives towards the spoken discourse analysis; definitions, examples, and application on it. They argue differently about some definitions of spoken discourse even though their arguments might be similar with Paltridge (2006) showing that students have their own understanding on what to define spoken discourse on their argument. Students also clearly might give some examples of spoken discourse that they express in their daily activity beyond the classroom while they join, discuss, speak, and interact with others. Meanwhile, in applying spoken discourse, students implemented in producing spoken discourse markers that help them in delivering the spoken message to participants or hearers.

\section{CONCLUSION}

The writers can conclude that from the students' perspectives towards spoken discourse about its definition, examples, and implications they mostly answer as they know as attending and deep giving attention on the discourse classroom. They define the spoken discourse as they assume that spoken discourse is a part of linguistics term that spoken discourse is dealing with the something lexical matters. Furthermore, it recommends that the way they give the examples since they tried to reveal the spoken discourse as their daily context within language education. Finally, the implications are also natural as the said that they apply it within their common conversation and interacting with people they talk.

\section{REFERENCES}

Arifuddin, M., \& Sofwan, A. (2015). Speech Functions and Grammatical Patterns Realization in Conversation in the English Textbook. Lembaran IImu Kependidikan, 44(1). 
Ary, Donald. (1985). Introduction to Research in Education: third edition. NewYork: CBS College Publishing.

Bharati, D. A. L. (2010). Teachers'professional Development through an Observation in Immersion Classes Based On the Documents and Teaching and Learning Processes. Language Circle: Journal of Language and Literature, 4(2).

Bharati, D. A. L. (2016, December). Developing Procedure Text Material Containing Fun Activities to Strengthen the Students 'Characters. In UNNES International Conference on ELTLT (pp. 181-184).

Blakemore, D. (1987) Semantic Constraints on Relevance. Oxford: Basil Blackwell.

Brian, P. (2006). Discourse Analysis an Introduction. New York: Continum.

Council, B. (2015). English in Colombia: An examination of policy, perceptions and influencing factors.

Creswell, J. W. (2002). Educational research: Planning, conducting, and evaluating quantitative (pp. 146-166). Upper Saddle River, NJ: Prentice Hall.

Dahal, B. (2010). Analysis of spoken discourse pattern in Nepali ELT classes. Journal of NELTA, 15(1-2), 22-27.

Demo, D. A. (2001). Discourse Analysis for Language Teachers. ERIC Digest.

Dijk, T. A. V. (1997). Discourse as social interaction. Discourse studies, 2.

Ekowati, A., \& Sofwan, A. (2014). The use of pragmatic deixis in conversation texts in pathway to english. Lembaran Ilmu Kependidikan, 43(2), 71-77.

Gay, L. R., Mills, G. E., \& Airasian, P. W. (1976). Educational research: Competencies for analysis and application. Columbus, $\mathrm{OH}$ : Merrill.

Ghasani, B. I., \& Sofwan, A. (2017). Appraisal and speech structure of contestants' speeches in speech contest of ESA WEEK competition. English Education Journal, 7(2), 152-159.

Hutchinson, T., \& Waters, A. (1987). English for specific purposes. Cambridge university press.

Johnson, K., \& Johnson, H. (Eds.). (1998). Encyclopedic dictionary of applied linguistics. Blackwell Publishing.

McCarthy, M., \& Carter, R. (2014). Language as discourse: Perspectives for language teaching. Routledge.

McCarthy, R. M. (Ed.). (1991). Political order and the plural structure of society (No. 2). Wm. B. Eerdmans Publishing.

McGrath, I. (2013). Teaching materials and the roles of EFL/ESL teachers: Practice and theory. A\&C Black.

Mujiyanto, Y. (2016). The comprehensibility of readable English texts and their backtranslations. International journal of English linguistics, 6(2), 21.

Munir, S., \& Nurkamto, J. (2013). An Evaluation of Reading Comprehension Textbooks Taught at The English Education Department of Islamic Higher Education in West Sumetera. Language Circle: Journal of Language and Literature, 7(2).

Nunan, D., \& Carter, R. (Eds.). (2001). The Cambridge guide to teaching English to speakers of other languages. Ernst Klett Sprachen

Paltridge, B. (2006). Discourse Analysis: An Introduction (London. Continuum) 
Permatasari, R., \& Bharati, D. A. L. (2015). students 'perception on the implementation of collaborative reasoning discussions (CR). English Education Journal, 5(2).

Richards, N. (2001). Movement in language: Interactions and architectures. Oxford University Press, USA

Riggenbach, H. (1999). Discourse analysis in the language classroom: Volume 1. The spoken language.

Rosari, L., \& Mujiyanto, Y. (2016). The effectiveness of know-want-learned and collaborative strategic reading strategies to teach reading comprehension to students with positive and negative attitudes. English Education Journal, 6(2), 33-41.

Schourup, L. C. (1985). Common Discourse Particles In English: 'Like', 'Well','Y'know'. New York: Garland.

Sinclair, J. and Coulthard, M. 1992. 'Towards an analysis of discourse'. In Coulthard, M.(Ed) 1992. Advances in spoken discourse analysis. 1-34. London: Routledge.

Sofwan, A., \& Suwignyo, E. (2011). The Realization of Disagreement Strategies by Non Native Speakers of English. Language Circle: Journal of Language and Literature, 6(1): 41-56.

Van Dijk, T. A. (1979). Pragmatic connectives. Journal of pragmatics, 3(5), 447-456.

Warner, R. (1985) Discourse connectives in English. New York: Garland.

Winter, G. (2000). A comparative discussion of the notion of validity in qualitative and quantitative research. The qualitative report, 4(3), 1-14. 